\title{
EVALUATION OF INTERDISCIPLINARY TEACHING APPROACH IN GEOGRAPHY EDUCATION
}

\author{
COĞRAFYA EĞİTIMINDE DİSİPLİNLERARASI ÖĞRETIMM YAKLAŞIMININ \\ DEĞERLENDİRILMESİ
}

\author{
Mustafa SAĞDIÇ ${ }^{1}$ \\ Hilmi DEMİRKAYA ${ }^{2}$
}

\begin{abstract}
The object of this study is to assess the interdisciplinary teaching approach in geography lessons in secondary education, based on the views of geography teachers in Turkey related to interdisciplinary teaching approach. Phenomenology design from qualitative research designs was applied in this study. Data obtained from this study was collected using "semi-structured interview form" conducted to geography teachers. The collected data was interpreted by considering the relevant literature, and some suggestions related with stakeholders were presented.
\end{abstract}

Key Words: Geography lesson, geography teacher, interdisciplinary teaching

Öz

Bu araştırma, Türkiye'de görev yapan coğrafya öğretmenlerinin disiplinler arası öğretime ilişkin görüşlerinden yola çıkarak ortaöğretim kurumları coğrafya eğitiminde disiplinler arası öğretim yaklaşımını değerlendirmektir. Araştırmada nitel araştırma yöntemi; nitel araştırma desenlerinden olgu-bilim deseni uygulanmıştır. Araştırmanın verileri, okul yöneticilerini uygulanan 'yarı yapılandırılmış görüşme formu' ile toplanmıştır. Görüşme kayıtlarının değerlendirilmesinde içerik analizi kullanılmıştır. Araştırma sonucunda elde edilen veriler ilgili literatür göz önünde bulundurularak yorumlanmış ve ilgili paydaşlara yönelik bazı öneriler sunulmuştur.

Anahtar Kelimeler: Coğrafya dersi, Coğrafya öğretmeni, disiplinler arası öğretim

\footnotetext{
${ }^{1}$ Yrd.Doç.Dr., Yıldız Teknik Üniversitesi, Eğitim Fakültesi, İlköğretim Bölümü, msagdic@yildiz.edu.tr

${ }^{2}$ Doç.Dr., Akdeniz Üniversitesi, Eğitim Fakültesi, İlköğretim Bölümü, hdemirkaya@akdeniz.edu.tr
} 


\section{INTRODUCTION}

The interdisciplinary concept means handling a concept, theme or problem through an integrated approach by using more than one discipline method and language (Jacobs 1989, Erickson 1995). In another words, interdisciplinary concept considers the richness of disciplines individually and interrelatedness of them, yet it also assumes that each problem in real world does not have a single correct answer (Perkins, 1994). Interdisciplinary approach is essentially based on holistic education. As a matter of fact, nothing can exist without a context in any kind; nothing is a standalone detached part (Miller, 2004). Interdisciplinary approaches, while arguably less effective than traditional approaches for building the depth of single-subject knowledge, emphasize higher-order thinking (e.g., analyzing, applying, generalizing) and seek meaningful connections between and among disciplines. (Ivanitskaya et al., 2002). On the other hand, the knowledge and skills earned through disciplinary approach don't seem to offer solution for problem encountered in daily life. Globalization, transition to information society and ecological and social developments occurring too fast has caused many problems to be resolvable with only interdisciplinary approach (Dervişoğlu and Soran, 2003). An interdisciplinary curriculum aims to solve complicated problems, which cannot be solved by using single discipline, with points of view developed by different disciplines (Repko, 2007). Traditional scientists have given priority and even partly superiority to their own fields. The main reason for that is the habit of explaining events and cases from their own perspectives. On the contrary, among the scientific studies performed in today's world of science, joint studies of disciplines that seems difficult have drawn attention and arouse interest. Therefore, it is required to schedule education and training process through an interdisciplinary approach. In this case, integration of deep knowledge put forth by disciplines separately is especially necessary to maintain the education and training process healthfully. However, some educators think that the integration of disciplines may be over loading for students while there are many difficulties of the main courses of individual disciplines (Reinhold and Bunder, 2001).

Interdisciplinary approach in education and training process emerge basically as interdisciplinary learning. Interdisciplinary learning causes someone to earn the abilities of enhanced thinking and learning skills, higher-order cognitive skills, improved content retention and devising connections between seemingly dissimilar contexts (Ackerman and Perkins, 1989). Interdisciplinary learning also plays a big role in earning the values such as; 
tolerating ambiguity or paradox, enlarged perspectives, syntheses and integration, creativity, original and unconventional thinking, critical thinking, creating balance between the objective and subjective thinking and going far from dogmatic information (Field et al., 1994). It is also important to determine the strengths and weaknesses of disciplines. Interdisciplinary learning is integration of multi-disciplinary information with content and objects of main curriculum. Interdisciplinary learning is required to create more holistic information than the information created in disciplinary studies. Also, interdisciplinary learning is a natural process which emerges as a pressure of mind in order for information to be transferred to the implementation and to be structured during thinking process. This process should not be prevented but should be managed well. At this point, the importance of teachers come to the forefront. Strict practitioners of disciplinary approach take a stand against this natural learning activity of mind unwittingly. Links with the information earned from other disciplines facilitates the learning of the main subject. For example, while handling immigration topic in a geography class, the student should not only be encouraged to correlate with migration of tribes learned in history class, migration stories listened in literature class or to migration activities of creatures instructed in biology class, but also timing of these related courses should be scheduled in curriculum accordingly. Some of the most important problems of today's education systems are those being unable to transfer information learned in the school to daily life, being unable to renew the knowledge and non-development of learning and research habit (Yıldırım, 1996). Since the education organized with only disciplinary approach may lead to problems in the establishment of a connection with real life and in using this information by integrating, it may make the education unappealing and decrease the motivation of students against the school. On the contrary, it is known that interdisciplinary teaching activities make positive contributions to cognitive, social and emotional developments of students and cause changes in the role of teacher (Demirel et al, 2008). Also, it was monitored that interdisciplinary approach increased the cooperation between the classes, the classes were more tasteful, the wish for performing scientific study and research was increasing and projects prepared by making connection with different disciplines developed the sense of global thinking and self-confidence (Diker 2004, Özkök 2004, Budak 2009, Alp 2010, Aslantaş 2012). For all these reasons, it becomes mandatory to structure all schedules (curriculums) through an interdisciplinary approach.

Preparation of curriculums with an interdisciplinary approach requires much information, time, cooperation and more efforts and experiences. While developing an 
interdisciplinary program, it is required to have experts from various disciplines as much as possible to contribute to this process. Also, an interdisciplinary program should be flexible enough due to personal differences in thinking process of students. Because; the individual differences in thinking process also provide opportunities to create alternative solutions while teaching course subjects to unsuccessful students. Therefore, there is no standard curriculum of interdisciplinary learning.

During the development process of an interdisciplinary program; primarily, the concept, theme or problems belonging to different disciplines to be taught should be determined through an interdisciplinary approach. The second important step is to establish the significant connections of this concept, theme or problems with other disciplines. It is mandatory for all addressees of different disciplines to take in charge in this process. It is critically important for incumbent educators to approach to the concept, theme or problems through an interdisciplinary perspective. For this reason, interdisciplinary education applications should be implemented in teacher education and teacher training programs. Besides, consideration of interests, expectations and skills of students and including them in student program development process and establishment of student groups are the other important steps. Of course, it may not be possible to give a place to all disciplines in the establishment of meaningful connection of concept, theme or problems determined through an interdisciplinary approach with different disciplines. However, it should not be forgotten that these concepts may be related with many disciplines. The establishment of these relations accurately is extremely important for the success of the program. As well as teaching the relevant subject in the interdisciplinary program development process, it is also important to include various skills and values to be earned in the program. In-class and extracurricular activities to be applied within the scope of program, especially the project works and the examinations should be handled through an interdisciplinary approach. The key criterion that the program has been developed as interdisciplinary is to ensure a general compliance between the classes in the school from the perspectives of subject, efficiency and skillstrategy simultaneously. Also, collaborative learning activities are required for both teachers and students during the implementation process of interdisciplinary teaching method (DiDonato, 2013). Especially, it is important for teachers of different classes to teach an interdisciplinary subject together in the same environment sometimes. 
Geography has emerged as an interdisciplinary field that integrates cross cutting technologies with arts and sciences education (Skole, 2004; Murphy, 2007; Taylor, 2009). Since the geography serves as a bridge between human and natural sciences in the sense of subject it has handled, the geography classes may be the most suitable classes for interdisciplinary teaching. From this perspective, there is almost no course not related with geography lessons in current education program. Basically, there is no science not related with location directly or indirectly which is the basic concept in geography. Spatial phenomena has been used often even in the studies performed on metaphysical topics. This makes geography, which is a science of places, related with all scientific fields. But, how the relationship of geography with other disciplines will be transmitted to education and training process? In other words, how geography lessons should be structured within interdisciplinary teaching programs? The answers of these crucial questions may provide a significant contribution to current problems of geography lessons. Sometimes, the mutual interaction is emphasized in geography education programs by taking examples from other scientific fields and disciplines (Ministry of National Education, 2012). On the other hand, the place of geography lessons in an interdisciplinary curriculum in general has not been adequately researched and enough experimental applications have not been performed on them. Our current study may create area of interest for researchers and is in a quality which may set up a substructure for other researches performed on the subject.

\section{METHOD}

This study has been designed in accordance with descriptive qualitative research design. Being appropriate to the nature of study, the phenomenology design has been used. The phenomenology design focuses on the cases that we are aware of but we do not have deep and detailed understanding. The phenomena may appear to us in the form of events, experiences, senses, tendencies, concepts and condition in the world we live in (Y1ldirım and Şimşek , 2005). Phenomenological research is based on the assumption that there is an essence or essences to share experience. The essences are the core meanings mutually understood through a phenomenon commonly experienced. The experiences of different people are bracketed, analyzed, and compared to identify the essences of the phenomenon. Phenomenological analysis attends to ferret out the essence or basic structure of a phenomenon. Several specific techniques-such as epoche, bracketing, imaginative variation, first- and second-order knowledge, and so on- are used to analyze experience (Patton 1990, 
Merriam 1998). Eighty seven geography teachers including 33 women $(37,5 \%)$ and 54 men $(61,4 \%)$ participated to the study from various schools of different districts of Istanbul (Table 1). A code starting from P1 to P87 was given for each participant to be used to express participant's interview results keeping their identity disclosed.

Table 1. Information of Participants

\begin{tabular}{llll}
\hline Variables & & F & \% \\
\hline Gender & Man & 54 & 61,4 \\
& Woman & 33 & 37,5 \\
\hline Type of school & High School & 23 & 26,1 \\
& Anadolu High School & 23 & 26,1 \\
& Vocational High School $^{3}$ & 19 & 21,6 \\
& Girls' Vocational School & 5 & 5,7 \\
& Religious High School & 9 & 10,2 \\
& Multi-program High School & 3 & 3,4 \\
& Private High School & 5 & 5,7 \\
\hline Work experience & $0-5$ & 23 & 26,1 \\
(year) & $6-10$ & 9 & 10,2 \\
& $11-15$ & 16 & 18,2 \\
& $16-20$ & 26 & 29,5 \\
& $21+$ & 13 & 14,8 \\
\hline
\end{tabular}

Experience level of geography teachers participated in the study, the numbers of experience in the teaching profession were as follows; $23(26,1 \%)$ teachers were between $0-5$ years, $9(10,2 \%)$ teachers were between 6-10 years, $16(18,2 \%)$ teachers were between 11-15 years, $26(29,5 \%)$ teachers were between 16-20 years and $13(14,8 \%)$ teachers were 21 and over years.

When the types of schools of the participant teachers were analyzed, it seem that 23 $(26,1 \%), 23(26,1 \%), 19(21,6 \%), 9(10,2 \%), 5(5,7 \%), 5(5,7 \%)$ and $3(3,4 \%)$ of the teachers works General High Schools, Anatolian High Schools, Vocational High Schools, Religious High Schools, Girls' Vocational School, Private High Schools and Multi-Program High Schools, respectively. Majority (76 persons; 87,4\%) of the participants emphasized that they had not received a training about interdisciplinary education previously. Few of the participants (11 persons, 12,6\%) emphasized that they had received a training on this matter, but the training was in theory and they were insufficient in practicing and they fell that they need a new training.

\footnotetext{
${ }^{3}$ Anatolian High School refers to public high schools in Turkey that admits their students according to high nation-wide standardized test scores.
} 
Deep and detailed information from the 87 geography teachers was collected by using semi-structured interview form of qualitative data collection techniques. Convenient random sampling method from purposeful sampling methods was used in the selection of geography teachers to be interviewed. Also, it was taken into consideration whether they accepted the participation or not. Convenient random sampling method contributed speed and practicality to the research.

The data acquired as a result of interviews with geography teachers was analyzed by using content analysis method. Content analysis requires the data collected to be analyzed in depth and it enables to emerge ambiguous themes and aspects (Yıldırım and Şimşek, 2005).

\section{FINDINGS}

\section{1-Are the topics of Geography class suitable for interdisciplinary education? Why?}

Although, the $87,4 \%$ (76 persons) of geography teachers think that the geography classes are suitable for interdisciplinary education, the $11,5 \%$ (10 persons) think that it is partially suitable and the $1,1 \%$ ( 1 person) think that it is not suitable.

Majority of those, who thought that geography classes are suitable for interdisciplinary education, attributed this suitability to the relation of geography with too many scientific fields. Even, some participants thought that geography is more or less related with all disciplines. They mostly attributed this to the extent of geography subjects. In this context, the following statements obtained from the study reflect the opinions of the participants in favor of the idea of the geography classes being suitable to interdisciplinary education:

P9: "The topics of geography sometimes intertwine with the topics of other classes", P68: "Since geography includes the topics related with all disciplines, it is suitable for interdisciplinary education", P44: "Since Geography is related with both social and physical sciences, it is suitable for interdisciplinary education", P51: "It is may be the most suitable one among other classes for interdisciplinary education. Almost there is no any topic that is not related even partially with geography", P75: "I think a geographer looks like a general practitioner medical doctor who starts from the whole, but when it comes to the details, who uses the knowledge of physic, chemistry, biology, mathematics, history and even literature". The following statements were also based on the idea that training and education process should fundamentally be structured according to interdisciplinary approach: P7: “A class not 
suitable for interdisciplinary education is not for sake daily life. A class not suitable for life is not a class rather it is a trouble", $\mathrm{P} 4$ : "Each class is definitely related with another class".

Those saying that geography classes were partly suitable for interdisciplinary education method thought that especially the density of the curriculum prevented the interdisciplinary activities. P86: "Especially, The intensity of geography class in $9^{\text {th }}$ grade obstructs interdisciplinary studies", K78: "Geography is partly suitable for interdisciplinary education, because of the density of curriculum". Only one participant stated that geography classes are not suitable for interdisciplinary teaching method. P85: "Geography is not suitable for interdisciplinary education since our methodology in geography teaching is completely different".

2-What do you think about communication and cooperation with teachers of other classes? Teachers of which disciplines that you communicate at most and least? Why?

When the question of "What do you think about communication and cooperation with teachers of other classes?" was asked to participants the answers were as follows; $81,6 \%$ (71 persons) of participant said that the communication was not enough while $18,4 \%$ (16 persons) said that it was enough. Following statements are related with failure of communication; P79: "There is not much cooperation; even the communication of geography teachers between themselves is weak", P24: "The communication is poor. This communication is especially poor in schools that have morning and afternoon classes separately due to heavy density of student population. ", P72: "Enough cooperation has not been accomplished. This should be encouraged by school administration". And, the following statements are excerpted from those participants claimed that the communication is sufficient; P41: "Our communication is good. We are especially good in communication with history and biology teachers", P36: “We are in communication with all branches. We communicate with the history teachers at most".

When the answers to question of "Which discipline teachers that you communicate at most and least?" were analyzed, it was seen that the participants communicated with teachers of history, biology, physic, chemistry, mathematics and literature (Table 2) in the order. However, the least communication, in vocational high schools, was seen with vocational class teachers and in other schools; the least communication was seen with the teachers of chemistry, literature, gym, mathematics, religion class and physic in the order. The classes 
such as literature, mathematics and chemistry were in both the least and the most communicated classes. History lesson was the most communicated lesson for geography teachers. Besides, no participant stated that history lesson was among the least communicated lessons. Some of participants stated that they communicated primarily with the teachers in physical sciences field while others stated that they communicated primarily with the teachers in social sciences. The following statements revealed a contradiction that some geography teachers are at good communication with physical science classes, however some of them are good communication with social science classes; P75: "I am in communication with physic, biology and chemistry teachers at most. Geography departments in universities should primarily accept students those who have physical science background in matriculation", P68: "I communicate with teachers of social sciences at most". Some of geography teachers (nine participants) emphasized that they were in communication with teachers of other classes in terms of human affairs rather than the context of communication classes. Following statements revealed this condition; P40: "The teachers communicate independently from different disciplines. They are rather related with human affairs than lessons", P59: "The cooperation is insufficient. Current communication is not related with lessons".

Table 2. The Communication of Geography Teachers with Other Teachers

\begin{tabular}{lcc}
\hline Lessons & \multicolumn{2}{c}{ Communication status } \\
& most (f) & least (f) \\
\hline History & 53 & - \\
Biology & 35 & 1 \\
Physic & 20 & 4 \\
Chemistry & 17 & 8 \\
Mathematic & 13 & 5 \\
Literature & 11 & 7 \\
Sociology & 5 & 1 \\
Philosophy & 2 & 2 \\
Religion & 1 & 4 \\
English & - & 2 \\
Psychology & - & 1 \\
Physical education & - & 5 \\
Music & 1 & 3 \\
Vocational high school lessons & 1 & 6 \\
\hline
\end{tabular}

3-Are interdisciplinary cooperation principles set by law implemented sufficiently by geography teachers towards communicating with other disciplines? 
The answers of participant to the above question are as follows; 57,5\% (50 persons) said "not implemented", 13,8\% (12 persons) said "partly implemented", 27,6\% (24 persons) said "being implemented" and 1,1\% (1 person) said "I don't have any opinion". Majority of participants thought that the cooperation principles to be made with other discipline teachers determined in geography teachers meetings remained on the paper only and not implemented sufficiently. Following statements were expressed by the majority of participants in a similar way; P13: "Not implemented. They remain on the paper only", P7: "Although this kind of cooperation principles are written in minutes of discipline teachers meetings with euphuism, they only remain on the paper and not implemented sufficiently", P63: "Due to density of lessons and since they have not been planned as interdisciplinary, they are not implemented sufficiently". Following statements revealed that the cooperation principles to be made with other discipline teachers determined in meetings were implemented partly; P67: "They are tried to be implemented in so far as the curriculum permits", P85: "The cooperation principles set by law can be implemented partly". Following statement reflected that the cooperation principles to be made with other discipline teachers determined in meetings were implemented; P30: "The cooperation principles are determined and implemented sufficiently".

4-Please specify advantages and disadvantages of teaching a topic or concept, which is already being taught in other lessons in the same week. (For example, when you teach the topic of migration in geography, the same topic might also be taught in literature, biology, history or music lessons with the methods and point of their own perspective in the same week)

When the participants were asked to specify advantages and disadvantages of teaching a topic or concept, which they taught in geography class, in other lesson in the same week; $86,2 \%$ (75 persons) answered in the positive way. This method was said to play an active role in consolidating the topic, earning different perspective for the topic, increasing the motivation of students and therefore making the learning easier. Following statements revealed this positive opinion; P3: "This method both cause to consolidate information and to gain a different perspective related with the topic", P68: "Different perspectives make the topics learned easier", P7: "It increases the desire for learning", P35: "It is suitable. It causes to consolidate the topics. It increases the communication between teachers". From the other side, the majority of those stating positive opinion said that this method might be possible if only curriculum would be rescheduled. Following statements were the examples of this 
thought; P2: "It is suitable. However, curriculum should be determined according to interdisciplinary approach", P41: "It is very suitable. However, the current curriculum is not suitable for this". P20 was worry about the possibility to make unnecessary duplications while having positive opinion about above the question mentioned above and stated that "It is suitable. But, students should not think that they repeat the same topics". It was understood that the majority of participants stating positive opinion had not implemented even had not heard this kind of methodology. While $8,1 \%$ of participants stated negative opinion, 5,7\% (5 persons) specified neither positive nor negative opinion. The following statements were the examples of negative opinions; P75: "This kind of application is not suitable in the same week", P71: "It is difficult to make in the same week", P60: "It is not suitable. It cause students to mix the topics", P42 "It is difficult to implement. Especially, it is difficult for crowded classes". Some of participants said that they could not constitute neither positive nor negative opinion without seeing the results of application.

\section{5-Is it appropriate to teach a topic in geography time to time together with other discipline teachers in the same classroom? Why?}

Majority of the participants, $67,8 \%$ of them (59 persons), stated positive and $31 \%$ of them (27 persons) declared negative opinions to the above question. Only one participant, $1,2 \%$, expressed neither positive nor negative opinion.. Following statements were related with the demonstration of positive results of this application; P7: "It would be very good. It makes the lesson funny", P9: "It might be good but an appropriate curriculum and class arrangement, and cooperation between the teachers from different disciplines are required to achieve this", P13: "It would be suitable. We have never tried up to now. It is a new application. I think that the results will be good", P16: "It would be suitable. It contributes consolidating the topic", P17: "It would be suitable. The students may gain different perspectives", P38 "It would be definitely suitable. It contributes to us, as teachers, to understand our insufficiencies". However, some of those stating positive opinions said that they had also some concerns. Following statements are evaluated in this context; P3: "It would be suitable. However, I worry that this may lead to confusion within the class. The physical conditions of schools should be appropriate", P14: "It would be suitable. However, there will be some problems in the application", P26: "It would be suitable. However, it is requires to solve the time and availability of classroom problems", P42: "It would be great. But, it is difficult to apply", P53: "It would be suitable, provided that it is not permanent". 


\section{6-What do you think about the competence of teachers on making interdisciplinary education? Should the teachers be given in service training related with interdisciplinary education method?}

When the participants were asked "What do you think about the competence of teachers on making interdisciplinary education?"; 56,3\% of them (49 persons) said that geography teachers were not competent on making interdisciplinary education, $18,4 \%$ of them (16 persons) said they were partly competent and 19,5\% of them (17 persons) said they were competent to do this. The teachers stating the following statements attributed this insufficiency on making interdisciplinary education to the lack of training related with this method; P1: "They are not sufficient. There is a need for in service training", P23: "They are not sufficient. No training has been given in the universities in this context", P83: "Their knowledge of geography is enough; however, the knowledge about the methodology of interdisciplinary teaching is not enough". Also, a significant number of teachers emphasized that the insufficiency was not in terms of lack of field knowledge, and especially the insufficiency was in terms of lack of interdisciplinary education method. P12 stated that the knowledge of geography teachers related with other disciplines is not enough. This way of thinking is based on the ideology about the interdisciplinary education in which it was thought that knowledge of other disciplines should be at a certain level for interdisciplinary education. Following statements were related with deficiency of availability level of teachers' interdisciplinary education; P8: "Since everybody thinks that their disciplines are important, they are not willing to cooperate", P13: "We are not inclined to work together", P41: "They are not enough due to lack of communication between teachers". The statement of P26: "They are insufficient. However, new generation teachers learn this in universities" pointed out the difference between young and old teachers related with interdisciplinary method. Almost all of participants thinking that geography teachers were sufficient on interdisciplinary method thought that inadequacy was not due to teachers themselves but it is due to the insufficiency incurrent curriculum. Following statements could be evaluated in this context; P11: "They are enough. But, the teaching environment is not suitable", P22: "They are enough. However, the curriculums should be tailored for this", P64 "The teachers are enough, but their motivations are weak".

When the participants were asked "Should the teachers be given in service training related with interdisciplinary education method?"; $78,2 \%$ of them (68 persons) answered "Yes. They should be given", 9,2\% of them (8 persons) said "No, not required" and 12,6\% of 
them (11 persons) said "I have no opinion". It was seen that those participants who have no opinion and those stated that in-service training was not required, they had generally some concerns related with the quality and dependability of in service training. Following statements were related with this concern; P8: "I think that there is lack of experts who can provide in service training", P14: "The person that will provide in service training should be expert", P20: "The in service training should be given by experts in this subject".

\section{8-Can all curriculums be programmed according to interdisciplinary education?}

When they were asked "Can all curriculums be programmed according to interdisciplinary education?"; 58,6\% of participants (51 persons) said this could be done, $27,6 \%$ of them (24 persons) said it could not be done, $13,8 \%$ of them (12 persons) said they did not have enough information whether it could be done or not. The teachers stating that all lessons could be scheduled in curriculum through an interdisciplinary method said that; the lessons naturally were in a complementary manner and all disciplines of science were essentially related with each other therefore this could be achieved.. Following statements showed this; K13: "It can definitely be done. All curriculums are complementary of each other", P39: "Yes, it can be applied. That it is interdisciplinary means that it is addressing to daily life". Some of those thinking that all curriculums could be programmed through interdisciplinary method emphasized that this would be difficult and professionalism would be required. Following statements were the examples for this; P72: "As a matter of fact, there is no science which can't be related with another", P52: "It can be done; however, many studied should be made on this", P67 "It could be done. Heads of all different discipline teachers should meet regularly". The statement of P44: "The program is already flexible in this matter. However, there are some inabilities in practice" was related with the opinion defending that current curriculums also showed the flexibility on this method, but interdisciplinary applications were not took place within this flexibility sufficiently. Some teachers thought that this could be done for not all curriculums but for some curriculums. P30: "This could be done. However, only the disciplines related with each other can be scheduled in curriculum in this way". The teachers thinking that not all lessons could be scheduled through an interdisciplinary approach thought that; this was because of the such reason as; weakness of adequacy of doing disciplinary training programs, lesson contents, interdisciplinary program currently, making morning and afternoon full day education in some schools due to crowded number students and unsuitability of curriculums in vocational 
high schools with interdisciplinary education. Following statements revealed this condition; P23: "The contents of some lessons make this impossible", P27: "It can't be done. The style for teaching each lesson is different from the other", P45: "It can't be done. There is a problem of lack of competent person in this matter", P47: "It is difficult especially in schools that have morning and afternoon full day education due to crowded number students", P48: "It is especially difficult for vocational high schools", P60: "No, it is not suitable. Each discipline should specialize in its own field".

\section{9-Has interdisciplinary approach been used in extracurricular activities (e.g. project studies)?}

When they were asked whether interdisciplinary approach was used in extracurricular activities (e.g. in project studies) or not, 72,5\% of participants (63 persons) said "It has not been used", 19,5\% of them (17 persons) said "it is partly used" and 8\% of them ( 7 persons) said "It has been used". The majority of those stating that interdisciplinary approach was not used sufficiently in extracurricular activities emphasized that the extracurricular activities could not be performed sufficiently. Following statements were in this context; P14: "It has not been used. The crowded classes and excessive course load of teachers limit the extracurricular activities", P42: "It has not been used. The extracurricular activities are already insufficient", P20: "It has not been used. Not many class-projects are made". Also, lack of motivation of teachers and students, crowded classrooms, excessive course load of teachers and current context of curriculums were expressed as the main disincentive factors. Following statements were related with application of interdisciplinary approach partly or sufficiently in extracurricular activities; P5: "Partly used. We plan field trips together", P70: "It has been used. Some of the project topics given increase the communication of students with other discipline lessons". 


\section{0-Do you think that school administration contributes to interdisciplinary education?}

When the participants were asked the question of "Do you think that school administration contributes to interdisciplinary education", 79,3\% of them (69 persons) said "They do not contribute" and 20,7\% of them said "They contribute". When those thinking that school administration did not contribute interdisciplinary education were asked "What should it be", they generally emphasized that they needed to contribute the establishment of physical infrastructure, preparation of curriculum and planning extracurricular activities. Following statements were examples to this; K3: "They do not contribute. Necessary organizations have not been made", , P28: "No contribution. They may provide support in preparation of class environment and curriculums". Also, some of participants attributed this insufficiency in contribution of school administration to interdisciplinary education to their inadequacy in performing teaching leadership. Following statements were evaluated in this context; P8: "No contribution. I think that school administrator has lost their sufficiency even in their own disciplines since they are on administrative position for long years", P11: "No contribution. This matter is actually a government policy it is nothing to do with the school administration", P13: "No contribution. Knowledge levels of school administrators are not enough", P21: "The school administration do not have this kind of planning", P40: "The school administration do not have time for teaching", P83: "The leaderships of school administrators are weak". Those saying that school administration contributed interdisciplinary teaching emphasized that this contribution was, in fact, limited with various recommendations. The statement of P9: "Cooperation between disciplines is recommended in yearly meetings at the beginning of each academic year" was example to this statement.

\section{1-What do you think about the approach of students to interdisciplinary teaching?}

When the participants were asked the question of "What do you think about the approach of students to interdisciplinary teaching?" $66,7 \%$ of them (58 persons) said "it would be positive", $25,3 \%$ of them (22 persons) said "it would be negative" and $8 \%$ of them (7 persons). The majority of those saying positive thought that this method could increase the motivation, make the lessons more fun and enjoyable and could make the learning easier. Following statements were related with positive opinion that were said; P1: "I think that the students will take more pleasure from this approach", P3: "I think this will attract the students", P11: "I think they will find this funnier", P22: "It would be positive. When students 
interrelate between lessons, this will facilitate learning", P7: "It would be positive. It will increase the teacher-student communication", P39: "It would be positive. It will remove the false image related with the disconnection of lessons from each other". While some of the participants placed positive opinion, they also thought that interdisciplinary method should not be used too often. P51: "It would be positive provided that it is not too often". Some of participants thought that the students would find the interdisciplinary teaching method favorable. Following statements were example to this opinion. P23: "They will orientate themselves in time", P70: "They may find it odd initially. I think they will adopt this in time". Other part of teachers thinking that the students would find interdisciplinary teaching method favorable said that they would approach in positive way since the young people were more open to change and innovation. P80: "It would be positive. Young people like the differences", P73: "The students are more open to changes. I think they will find it favorable".

Few of the participants think that the students would take a dim view of interdisciplinary approach due to reasons of such as; interdisciplinary program would increase the course load of students and lead to confusion. P21: "They may approach in negative way. They think that their course load may increase", P43: "This kind of program may bring confusion", P83: "The students are already reluctant against education and training activities". The teachers in undecided attitude about the approach of students related with interdisciplinary education approach attributed this instability to the uncertainty related with the results of the method and difference in approaches of students related with lessons. Example to this statement are; P55: "I can't say anything before seeing the application results", P15: "It will create difference for students interested in lessons, but the students not interested in lesson will disrupt the class".

\section{2-Are the facilities of school adequate for interdisciplinary education? If they are adequate, are they used for interdisciplinary education?}

When the geography teachers were asked "Are the facilities of school adequate for interdisciplinary education? If they are adequate, are they used for interdisciplinary education?", 72,4\% of them (63 persons) said "not adequate", 24,1\% of them (21 persons) said "adequate" and 3,5\% of them (3 persons) said "partly adequate". 52,4\% of those (11 persons) saying that the facilities of school were adequate for interdisciplinary education thought that these facilities were not used for interdisciplinary education, $23,8 \%$ of then ( 5 persons) thought they were partly used and another $23,8 \%$ of them ( 5 persons) thought they were used adequately. 


\section{DISCUSSION AND CONCLUSIONS}

The large majority of geography teachers think that geography lessons are suitable for interdisciplinary teaching. This opinion is related with geography being an interdisciplinary science. The geography scientists have sometimes completely deviated from principles of geography during interdisciplinary studies and almost left geography and directed their research interest to the other disciplines. Solid defenders of geography disciplinary have fallen into another mistake as being opposition to interdisciplinary education in geography science. However, interdisciplinary approach is not against disciplinary approach; on the contrary, it is complementary of it. This problem encountered during academic researches emerges in a different perspective during training and education process. Especially, the interdisciplinary studies to be performed without deviating from original principles of geography discipline may contribute both solving the problem of identity of geography and developing the science of geography. Interdisciplinary teaching method is such a method that geography teachers have applied sometimes intentionally or sometimes without being aware of yet they can't give up this teaching method.

The minor group of geography teachers is of the opinion that geography lessons are not suitable enough for interdisciplinary education method. This opinion, of course, is not related with the topics of geography but it is because of the characteristics of the current curriculum followed in Turkish education system. Those stating that geography curriculums are not suitable enough for interdisciplinary education method complain that especially the geography curriculum of $9^{\text {th }}$ grade does not give opportunity to interdisciplinary activities. Even, some of geography teachers think that weekly course hours are not enough to complete geography curriculum of $9^{\text {th }}$ grade. Under these circumstances, especially, it is almost impossible to allocate time for interdisciplinary activities in $9^{\text {th }}$ grade. Performing interdisciplinary activities within current curriculum that is the end-result of disciplinary approach, requires extra time which means additional course load for both teacher and student. Only solution for this problem is to revise current curriculum in accordance with interdisciplinary teaching method.

Majority of geography teachers think that the communication and cooperation with the teachers of other disciplines in their school is not enough. It is obligatory by law to determine principles of cooperation to be made with teachers of other disciplines (Ministry of National Education, 2010). The inadequacies of teachers in professional cooperation are 
related with following reasons; they have not been encouraged to associate their subject areas with other disciplines; current curriculum has not been prepared with an interdisciplinary understanding; and the teachers are not ready enough to work together. On the contrary, the curriculums prepared according to interdisciplinary approach may contribute both learning significantly and increasing the professional cooperation between the teachers.

The teachers that the geography teachers communicated mostly are history teachers. This connection, in fact, is closely related with the emergence expedition of sciences of history and geography and basically it is based on the relationship of time and location. The science of history is mostly defined as "the science explaining the events, which human communities have created in the past, by specifying time and location within the principle of cause and effect" (Öztürk, 1999). As it can be understand from this definition, the explanation of historical events by specifying location, in other words, by associating it with geography is one of basic principles of this science. The changes of natural and humanitarian events based on the time and space determine the dynamics of geography science which, therefore, requires the cooperation between sciences of geography and history. Geography teachers make the second most cooperation with biology teachers after history teachers. This is because of the place of biology among the sciences assisting the science of geography and the weight of biology topics in current curriculum of geography. The sciences of "phytogeography" and "zoogeography" of physical geography are closely related with botanic and zoology which are the main subjects of biology. It cannot be said that the geography teachers are in a planned cooperation with the teachers of other disciplines. In fact, the lessons such as mathematics, chemistry and physic are among the most and least communicated lessons. However, there are some geography topics that require cooperation with the lessons such as physic, chemistry, mathematics and literature. On the other side, new geography curriculums should encourage reading literary products such as novel, story, memory, travel writing, poem and joke that may popularize the topics related with geography (Ministry of National Education, 2012). The communication of geography teachers with the teachers of lessons of literature, music and gym, which are quite suitable for interdisciplinary in-class and extracurricular activities, appears to be extremely weak.

Geography teachers are mostly enthusiastic about the opinion of teaching an interdisciplinary topic or concept in geography (e.g. teaching the topic of migration in geography in the same week together with teaching the same topic with the methods and 
perspectives of literature, biology, history or music lessons) with the methods and perspectives of other discipline lessons in same week. This method of teaching will play an active role in consolidating the topic, earning different perspective for the topic, increasing the motivation of students and therefore making the learning easier. However, it is clear that the success will be possible with only revising all curriculums through an interdisciplinary understanding which requires a good planning and organization. In fact, interdisciplinary program requires more effort and cooperation compared to disciplinary approach. An interdisciplinary program to be prepared without making the expected cooperation and effort may lead to some negativities such as; making some unnecessary repetitions, some setbacks in annual education program and waste of time and unwillingness in students.

The first step for teaching an interdisciplinary topic in another discipline lesson with the method and perspective of that lesson in same week is to determine the topic. Primarily, the topic should be as current as possible and wide-ranging topic which may attract the students' attention. In the second step, the disciplines that the topic may be related with should be determined. While determining the relevant discipline, it is important to determine the disciplines directly related with the topic first of all (Y1ldırım, 1996). Including disciplines which may be indirectly related with the topic may lead to negativities above mentioned. It is also important for those developing the program not to have a concern related with including too many disciplines to the program. The role of teachers to be included in the program is important to apply this application successfully. It is important for teachers included in the program to endeavor much effort in the preparation phase as compared with disciplinary approach and especially to have concern for reflecting the perspective of their disciplines on the topic completely. Otherwise, some redundancies may occur. The success in interdisciplinary teaching depends mostly on configuring the relations between theories, approaches, research methods, concepts and paradigms. This configuration requires knowing different perspectives of disciplines. Also, the references required for students to make said association should be determined (Ivanitskaya et al., 2002). In this stage, the coordination between the teachers of program will play an important role.

While the teachers, for an interdisciplinary lesson to be given at same location by different discipline teachers, showed a positive approach, on the other side, they expressed more concerns compared to previous application. These concerns are related with that the students and teachers are not ready enough for this kind of application. Especially, they 
thought that the teachers do not have ability to work together. However, one of the most important factors for an interdisciplinary program to be successful is cooperation of teachers (Duman and Aybek, 2003). Although interdisciplinary applications include some difficulties in start-up phase, it should not be forgotten that they may contribute increasing the professional cooperation between the teachers in a positive way. One of the important problems while more than one teacher makes an interdisciplinary lesson application at the same location is the inadequacy of physical facilities. There is a need for interdisciplinary classrooms designed expediently for interdisciplinary lessons (Woods, 2007). However, it can be said that a great majority of schools are not adequate in this respect. Majority of geography teachers expressed a view in this respect in the study. Also, it is mandatory have a good planning and organization for this kind of application.

Geography teachers in the study mostly said that they were not sufficient in making interdisciplinary teaching and this was because of lack of education basically. On the other side, a great majority of teachers did not have information on interdisciplinary teaching (Dervişoğlu and Soran, 2003). Since the teachers have not been encouraged to associate their disciplines with other disciplines, they try to transfer information to their students related with only their lessons and they do not point out at which level the information and skills learned in these lessons are used in other lessons or how the connection is made. For this reason, interdisciplinary teaching has become important with such applications as new teacher training programs, group teaching and problem based education. The teachers attribute their inadequacies in interdisciplinary teaching to excessive course load and hectic work schedule other than lack of training. Thus, they complain about not having enough time for interdisciplinary activities. Therefore, it is necessary to make teachers create time for interdisciplinary teaching by decreasing their duties and responsibilities. Teachers need to be adequately supported in terms of workload, career rewards and pedagogy (Pharo and Bridle, 2012).

Majority of geography teachers in the study expressed that they did not receive training on interdisciplinary teaching. Almost all of those stating that they had received training emphasized that it was in theory and they were inadequate in practice and in-service training needed to be given.

Geography teachers of $58,6 \%$ of (51 persons) in the study were of the opinion that all curriculums could be programmed in conformity with the interdisciplinary teaching 
because of the fact that all lessons are naturally complementary to each other and all sciences were originally related with each other. However, they emphasized that it would be difficult and require professional help. Some of teachers thought that all curriculums could not be programmed in conformity with the interdisciplinary teaching by reason of weakness of ability to make interdisciplinary program through basic disciplinary curriculum and lesson contents. Teachers of 13,8\% (12 persons) in the study group said that they did not have enough information on this matter. Curriculums have been generally designed inadequately for interdisciplinary teaching. Conventional teaching approaches are more apt to handle the topics within rigid rules of disciplinary approach. However, it should be well known that more advanced epistemological beliefs, enhanced critical thinking ability, metacognitive skills and an understanding of the relations among perspectives derived from different disciplines will develop in students through interdisciplinary approach (Ivanitskaya et al., 2002).

Developing the curriculums through interdisciplinary approach also means the integration of curriculums of different disciplines. Integration of different disciplines increases the cognitive development, abstract thinking, creativity and problem-solving skills (Perkins, 1994). For this reason, the curriculums developed through interdisciplinary approach should first and foremost be flexible. It is necessary to establish connections between various disciplined and interdisciplines. The integration of teaching will be a pragmatic use of disciplines (Duman and Aybek, 2003). The integration properly of topics from different fields may cause individual to take part in learning experiences and therefore to the realization of a better learning. Also, the integration of different disciplines will prevent excessive accumulation of topics and increasing disintegration of the time (İşler, 2004). In this case, the curriculums developed through interdisciplinary approach not only require extra time but also prevent the waste of time. Also, the integration of curriculums of different disciplines is mandatory for realizing the common purposes of school. There may be different ways for integrating the curriculums; however, the teachers may also develop their own method for integrating curriculums (Gürkan and Gökçe, 1999).

Majority of geography teachers in the study said that the interdisciplinary approach was not used in extracurricular activities (e.g. project works) sufficiently. Also, the teachers emphasized that the basic problem was that the extracurricular activities were not carried out sufficiently. Lack of motivation of teachers and students, crowded classrooms, excessive 
course load of teachers and current context of curriculums were expressed as main disincentive factors. However, extracurricular activities have vital importance in the integration with society. In other words, the school establishes the communication with society mostly through extracurricular activities. Planning the extracurricular activities will contribute students to plan their daily lives. It is also known that extracurricular activities contribute the academic achievement, establishment of school culture, self-development and some social skills in the students (Köse, 2003). Extracurricular activities generally necessitate an interdisciplinary approach. This is because; these activities require more than one discipline to work jointly. Geography as a discipline lends itself particularly well to learning experiences outside the classroom. Informal learning environments, such as a model railroad exhibit at a history museum, can be exploited to introduce key geographic concepts (e.g., scalar compression, landscape transformations, and human environment interaction) (Bloodworth and Petersen). Also, these activities may be either at or out of school. Especially, the project papers have important place. Project-based teaching also requires interdisciplinary approach. Since project-based teaching model requires perspectives of different disciplines, it is usually a nested method with interdisciplinary teaching method (Mancas, E.A., 2011). Field trips include any learning experience that occurs outside a classroom. Field trips have been acknowledged as valuable learning experiences in geography (Manner, 1995; Kent, Gilbertson, and Hunt 1997; Hefferan, Heywood, and Ritter 2002, Krakowka 2012). Field trips should be also planned through an interdisciplinary approach. The aim of all disciplines is for individual to adapt natural and social environment. Planning the land applications through an interdisciplinary approach will make a great contribution to realize common purposes of school. The inadequacy in the facilities (e.g. laboratory, material etc.) of schools in terms of teaching interdisciplinary teaching and disuse of present facilities sufficiently for interdisciplinary teaching is an important problem.

The majority of geography teachers in the study had negative opinion on the contribution of school administration to interdisciplinary teaching. The teachers usually require schools to assume responsibility on establishment of physical infrastructure, preparation of curriculum and planning extracurricular activities. This is because; the teachers and school administrators should be ready for close cooperation and for finding solutions related with time, content and location by creating timeframes such as block schedule lessons (consecutive hours for a lesson) or project weeks (Schoch and Seitz, 1997). The less support from the school management for interdisciplinary teaching programs is usually related with 
their insufficient teaching leaderships. Among the factors limiting the educational leaderships of school administrators; bureaucratic and legal obstacles, time restrictions, lack of education, vision, determination, lack of courage and resource shortage draw the attention (Gümüşeli, 1996).

Majority of geography teachers in the study did not have positive opinion on how the students would react interdisciplinary teaching. The teachers were of the opinion that this would increase motivation, make lessons more fun and make the learning easier. The curriculums organized with this understanding may make the learning enjoyable by causing students to establish a connection with real life and use the information by integrating, and may increase the willingness of students towards the school and learning. From the other side, interdisciplinary approach has a great importance in terms of guaranteeing the teaching by means of enlivening the learning environment, developing the creativity of students and, most importantly, making them more willing towards the lessons (Aybek, 2001).

\section{REFERENCES}

Ackerman, D. B. (1989). Intellectual and practical criteria for successful curriculum integration. In H. H. Jacobs (Ed.), Interdisciplinary curriculum: Design and implementation. (pp. 25-38). Alexandria, VA: Association for Supervision and Curriculum Development.

Ackerman, D. B. \& Perkins, D. N. (1989). Integrating thinking and learning skills across the curriculum. In H. H. Jacobs (Ed.), Interdisciplinary curriculum: Design and implementation. (pp. 77-96). Alexandria, VA: Association for Supervision and Curriculum Development.

Alp, E. (2010). The effect of interdisciplinary teaching approach on students' academic successes and permanence of learning in probability subject, Karadeniz Technical University, Institute of Science (unpublished master's thesis), Trabzon.

Aslantaş, S. (2012). The effectiveness of applying inter-disciplinary approach in visual arts class, Gazi University, Institute of Education Sciences (unpublished phd thesis), Ankara.

Aybek, B. (2001). Interdisciplinary (holistic) teaching approach, Eurasian Journal of Educational Research, 3, 1-7.

Bloodworth, G. \& N. J. Petersen (2011). Developing Visualization Tools for Geographic Literacy in a Museum Exhibit: An Interdisciplinary Collaboration, Journal of Geography, 110(4), 137147

Budak Coşkun, S. (2012). The effect of the implementation of interdisciplinary approach in 8th grade lessons of mathematics on mathematical achievement of students, Kalem Eğitim ve İnsan Bilimleri Dergisi, 2 (2), 91-122.

Dervişoğlu, S. \& Soran H. (2003). Evaluation of interdisciplinary teaching approach in high school biology education, Hacettepe University Journal of Education, 25 : 48-57.

Demir, E. (2009). Holistic approach to teaching in second year primary impact of interdisciplinary applied, Selcuk University, Institute of Social Sciences (unpublished master's thesis), Konya. 
Demirel, O., Tuncel, I., Demirhan, C. \& Demir, K. (2008). Teacher and pupil views about activities based on multiple intelligences and the interdisciplinary approach, Education and Science 33(147), Ankara.

DiDonato, N. C. (2013). Effective self- and co-regulation in collaborative learning groups: An analysis of how students regulate problem solving of authentic interdisciplinary tasks, Instructional Science 41,25-47.

Diker, Y. (2004). A case study about interdisciplinary teaching approach, Hacettepe University, Institute of Social Sciences (unpublished master's thesis), Ankara.

Duman, B. \& Aybek, B. (2003). A comparison of the approaches of process-based and interdisciplinary instruction, Mugla University, Journal of Social Sciences Institute, 11, 1-12.

Erickson, H.L. (1995). Stirring the head, heart, and soul. Redefining curriculum and instruction. California: Corwin Press, Inc.

Field, M., Lee, R. \& Field M. L. (1994). Assessing interdisciplinary learning. New directions for teaching and learning, 58, 69-84.

Gümüşeli, A. İ. (1996). Okul Müdürlerinin Öğretim Liderliğini Sınırlayan Etkenler. Eğitim Yönetimi, 2(2), 201-209.

Gürkan, T. \& Gökçe E, (1999). Eğitim Proğramlarını Bütünleştirmenin On Yolu, Ankara University, Ankara University, Journal of Educational Sciences Faculty, 32 (1).

Hefferan, K. P., N. C. Heywood \& M. E. Ritter, 2002. Integrating field trips and classroom learning into a Capstone undergraduate research experience. Journal of Geography 101 (5), 183-190.

Ivanitskaya, L., Clark, D., Montgomery, G. \& Primeau, R.,(2002). Interdisciplinary Learning: Process and Outcomes, Innovative Higher Education, 27: 2.

İşler, A. (2004). Sanat Eğitiminde Disiplinler arası-Tematik Yaklaşım. Milli Eğitim, 163,43-53.

Jacobs, H. H. (1989). Interdisciplinary curriculum: Design and implementation. Alexandria, VA: Association for Supervision and Curriculum Development.

Kent, M., D. D. Gilbertson \& C. O.Hunt (1997). Fieldwork in geography teaching: A critical review of the literature and approaches. Journal of Geography in Higher Education 21 (3), 313-332.

Krakowka A. R. (2012). Field Trips as Valuable Learning Experiences in Geography Courses, Journal of Geography, 111(6), 236-244

Köse, E. (2003). "Erzurum Ilindeki Ilköğretim Okullarında Ders Dışı Etkinliklere Yönelik Altyapı Olanakları ile Ilgili Bir Ön Araştırma”, Kazım Karabekir Eğitim Fakültesi Dergisi 7, Erzurum.

Mancas, E.A. (2011). When learning and assessment become meaningful: students get involved in interdisciplinary project-work, Procedia Social and Behavioral Sciences 11, 205-209.

Manner, B.M. (1995). Field studies benefit both students and teachers. Journal of Geographical Education 43 (2), 128-131.

Merriam, S. B. (1998). Qualitative research and case study applications in education. San Francisco: Jossey-Bass.

Ministry of National Education (M.E.B) (2012), Talim ve Terbiye Kurulu Başkanlığı. Coğrafya Dersi Öğretim Proğramı ( 9, 10, 11 ve 12. Sinıflar), Ankara.

Ministry of National Education (M.E.B) (2010).Ortaöğretim Kurumları Yönetmeliği, Madde 36, Ankara.

Murphy, A. B. (2007). Geography's place in higher education in the United States. Journal of Geography in Higher Education 1 (1), 121-141. 
Miller R. (2005). Bütüncül Eğitimin Felsefi Kaynakları, Journal of Values Education -Turkey, 3 (10), $33-40$.

Özkök, A., (2004). The effect of interdisciplinary art on creative problem solving skills and a model suggestion, Gazi University, Institute of Education Sciences, unpublished phd thesis, Ankara.

Öztürk, M. (1999). Tarih Felsefesi, Ankara: Başbakanlık Yayınları.

Perkins, D.N. (1994). The Intelligen eye. Sanat Monica, CA: The Getty center for education in the arts.

Patton, M.Q. (1990). Qualitative Evaluation and Research Methods. Newbury Park;. London: SAGE.

Pharo E \& Bridle K (2012). Does Interdisciplinary Exist Behind the Façade of Traditional Disciplines? A Study of Natural Resource Management Teaching, Journal of Geography in Higher Education, 36(1), 65-80

Reinhold, P. und Bunder, W. (2001). Stichwort: Facherubergreifender Unterricht. ZfE 3 (Tradiertes Wissen in der Schule), s. 333-359.

Repko, A. F. (2007). Interclisciplinarv curriculurn design, Academic Exchange Quarterly, 11(1), 130137

Schoch, E. und Seitz, H. (1997). Interdisziplinarer Unterricht- Anspruch und Wirklichkeit. 25 Jahre IWP. Schule in Wissenschaft, Politik und Praxis, Dubs, R. und Luzi R. (Hrsg.), St. Gallen, 633-645.

Sahbaz N M \& Cekici Y E, (2012). Turkish education as an interdisciplinary discipline, Turkish Studies, 7(3), 2367-2382.

Skole D L, (2004). Geography as a great intellectual melting pot and the preeminent interdisciplinary environmental discipline, Annals of the Association of American Geographers, 94(4),739743.

Taylor, C. (2009). Towards a geography of education. Oxford Review of Education 35 (5), 651-669.

Woods, C. (2007). Researching and developing interdisciplinary teaching: towards a conceptual framework for classroom communication, High Education 54,853-866

Yarımca, O. (2011). A case study in interdisciplinary approach, Akademik Bakış Dergisi, 25, 1-22.

Yıldırım, A. \& Şimşek, H. (2006). Sosyal Bilimlerde Nitel Araştırma Yöntemleri. Seçkin Yayıncılık, Ankara.

Yıldırım, A. (1996). Disiplinlerarası Öğretim Kavramı ve Proğramlar Açısından Doğurduğu Sonuçlar, Hacettepe University Journal of Education, 12, 89-94. 